\title{
1 Photoswitchable Serotonins for Optical Control of the 5-HT2A Receptor
}

2 Johannes Morstein ${ }^{1 \#}$, Giovanna Romano ${ }^{2 \#}$, Belinda E. Hetzler ${ }^{1}$, Ambrose Plante ${ }^{2}$, Caleb Haake ${ }^{1}$, Joshua 3 Levitz ${ }^{2 *}$, Dirk Trauner ${ }^{1 *}$

4

$5 \quad{ }^{1}$ Department of Chemistry, New York University, New York, New York 10003, United States.

$6 \quad{ }^{2}$ Physiology, Biophysics and Systems Biology Graduate Program and Department of Biochemistry, Weill

7 Cornell Medicine, New York, NY 10065, USA.

$8 \quad$ *e-mail: jtl2003@med.cornell.edu; dirktrauner@nyu.edu 


\section{Abstract}

10 The serotonin receptor family of G protein-coupled receptors (GPCRs) and ligand-gated ion channels play 11 central roles in neuromodulation and are critical drug targets for the treatment of psychiatric disorders.

12 Optical control of serotonin receptor subtypes has the potential to greatly enhance our understanding of 13 the spatiotemporal dynamics of receptor function both at the cellular level and within neural circuits. While 14 other neuromodulatory receptors have been successfully rendered photoswitchable, reversible 15 photocontrol of serotonin receptors has not been achieved, representing a major gap in GPCR 16 photopharmacology. Herein, by designing and screening a family of azobenzene-conjugated serotonin 17 analogues, we developed the first photopharmacological tools that allow for such control. Azo5HT-2 18 shows light-dependent $5-\mathrm{HT}_{2 \mathrm{~A}} \mathrm{R}$ agonism, inducing receptor-mediated calcium signaling in the light19 activated cis-form. Based on computational docking and test compound analysis, we also synthesize and

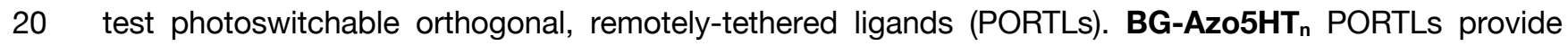
21 rapid, reversible and repeatable optical control following conjugation to SNAP-tagged $5-H T_{2 A} R$. Overall, 22 this study both introduces new tools for the optical control of 5- $\mathrm{HT}_{2 \mathrm{~A}} \mathrm{Rs}$ and provides a foundation for the 23 broad extension of photopharmacology to the serotonin receptor family. 
Serotonin (5-hydroxytryptamine; 5-HT) is a neuromodulator that is released in the brain primarily by Dorsal Raphe Nuclei neurons, in the gut by enterochromaffin cells, and in blood platelet cells. ${ }^{1,2}$ Serotonin acts through a large family of $\mathrm{G}$ protein-coupled receptor $\left(5-\mathrm{HT}_{1} \mathrm{Rs}, 5-\mathrm{HT}_{2} \mathrm{Rs}, 5-\mathrm{HT}_{4} \mathrm{Rs}, 5-\mathrm{HT}_{5} \mathrm{Rs}, 5-\mathrm{HT}{ }_{6} \mathrm{Rs}, 5-\right.$ $\left.\mathrm{HT}_{7} \mathrm{Rs}\right)$ and ion channel $\left(5-\mathrm{HT}_{3} \mathrm{Rs}\right)$ subfamilies to regulate a plethora of neuronal and behavioral processes. ${ }^{1}$ Given the importance of 5-HT to the regulation of mood, cognition and reward, great effort has been made to harness pharmacology to manipulate 5 -HTRs for both basic study and therapeutic applications. Recent developments establishing the potential of $5-\mathrm{HT}_{2 \mathrm{~A}} \mathrm{R}$-targeting psychedelic drugs for the treatment of depression, anxiety, and addiction have further motivated the detailed study of 5-HTR signaling. ${ }^{3-7}$ Despite great attention, limitations in the ability of 5-HTR-targeting compounds in terms of subtype-specificity and spatiotemporal precision and their inability to be targeted to genetically defined cell types have hindered progress toward a mechanistic understanding of the physiological and therapeutic effects of 5-HTR signaling.

As an alternative to classical pharmacology, photopharmacology has emerged as a means of gaining further precision through the development of photosensitive compounds whose activity can be modified depending on the wavelength of illumination ${ }^{8-10}$. Photopharmacological compounds have enabled the optical control of a variety of GPCRs, including class A ( $\mu$-opioid receptor, ${ }^{11}$ dopamine receptors,,${ }^{12,13}$ histamine receptors, ${ }^{14}$ adenosine receptors, ${ }^{15}$ muscarinic receptors, ${ }^{16}$ adrenergic receptors ${ }^{17}$, fatty acid receptors, ${ }^{18}$ lysophospholipid receptors, ${ }^{19,20}$ and cannabinoid receptors ${ }^{21,22}$ ), class B (glucagon-like peptide 1 receptor $^{23,24}$ ), and class C GPCRs (metabotropic glutamate receptors ${ }^{25-28}$ ). For further precision, including the ability to target the effects of light to genetically-defined cell populations, photopharmaceuticals may be covalently tethered to a genetically engineered receptor containing a labeling domain (i.e. SNAP, Halo) as Photoswitchable Orthogonal Remotely Tethered Ligands (PORTLs), as has been demonstrated with metabotropic glutamate receptors (mGluRs). ${ }^{29,30}$ mGluR-targeting PORTLs have been applied for both

48 molecular biophysical studies ${ }^{31}$ and the in vivo manipulation of mGluR2 in specific cell types ${ }^{32-34}$ in behaving 49 mice, providing a template for their development and application in complex systems. 
50 Surprisingly, 5-HTRs have received limited attention in terms of photopharmacology. Photocaged variants 51 of serotonin have enabled light-induced release of $5-\mathrm{HT}$ through removal of photocleavable protecting 52 groups. ${ }^{35-38}$ However, these tools do not offer reversible control, lack 5-HTR subtype targeting, and have 53 not been paired with genetic targeting as can be done with PORTLs. ${ }^{29,30,39}$ Thus, the development of a 54 photoswitchable ligand platform for the 5-HTR family would enable the study of these receptors with 55 unprecedented spatiotemporal control, which could facilitate new insight into the dynamics of neural 56 signaling. Herein, we describe the first development of a series of photoswitchable ligands for the $5-\mathrm{HT}_{2}$ receptor family. We identify an azobenzene-conjugated 5-HT lead compound, Azo5HT-2, that enables optical control of $5-\mathrm{HT}_{2 \mathrm{~A}} \mathrm{Rs}$ with activity which is increased approx. 10-fold in the cis form upon irradiation.

59 Computational structural analysis suggests that the 5-HT moiety of cis-Azo5HT-2 binds with a canonical pose and enables access to the azobenzene ring from the extracellular face of the receptor, motivating the

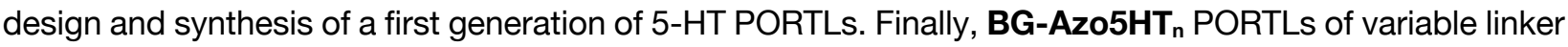
length enable repeatable optical control of SNAP-tagged $5-\mathrm{HT}_{2 \mathrm{~A}} \mathrm{R}$, opening the door to genetically targeted, receptor-specific optical control of serotonergic signaling.
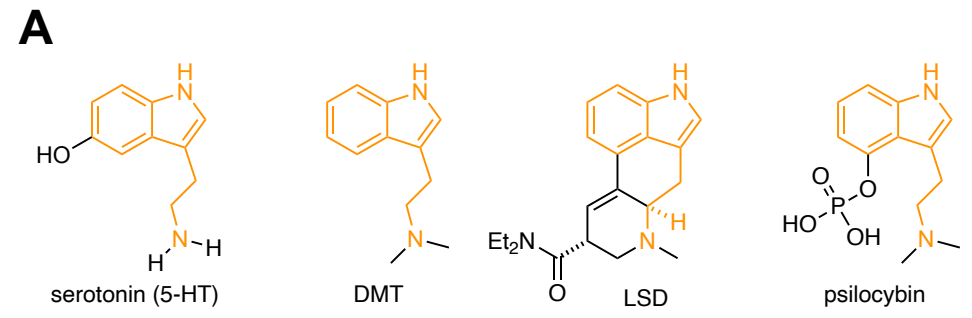

B
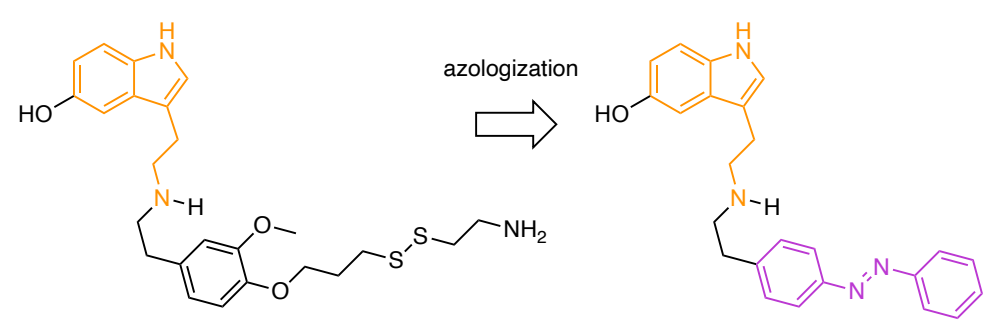

65 Figure 1. (A) Representative tryptamine-derived agonists of 5-HT receptors: serotonin, PNU 22394, LSD, and psilocybin. Shared tryptamine moiety highlighted in orange. (B) Azologization strategy ${ }^{40,41}$ for the design of photoswitchable agonists based on a previously-reported covalent agonist of 5-HT2A (left). ${ }^{42}$ 
The 5-HT receptor family is targeted by a variety of natural and synthetic agonists, including many with a tryptamine (indolamine) moiety (Fig. 1A). We considered several of these ligands for the design of photochromic agonists but reasoned that serotonin would be best suited because analogs would likely mimic endogenous signaling and derivatives which could be suited for incorporation of azobenzene motifs have been reported previously. These derivatives include covalent 5-HT analogs with an appended benzene ring (Fig. 1B). ${ }^{42}$ We considered an 'azologization'40,41 approach to install the azobenzene at the matching position (Azo5HT-3) and designed additional derivatives with the azobenzene moved one carbon atom closer to the pharmacophore (Azo5HT-1 and Azo5HT-2). The derivatives were synthesized through reductive amination of 5-HT with the corresponding azobenzene-aldehydes (Fig. 2 A,B). Photophysical characterization of Azo5HT-1 to Azo5HT-3 (Fig. 2 C,D and Fig. S1) revealed similar properties to classical azobenzenes. All derivatives could be reversibly switched to their respective cis and trans forms with UV-A (365 nm) and blue light $(460 \mathrm{~nm})$, respectively, and underwent slow thermal relaxation $\left(\mathrm{t}_{1 / 2}>1 \mathrm{~h}\right)$.

A

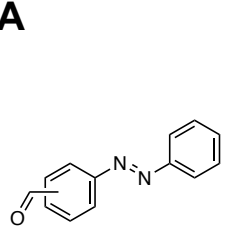

B

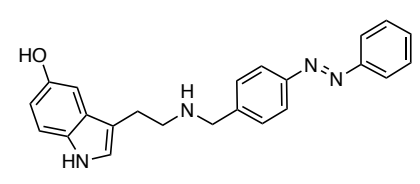

trans-Azo5HT-1

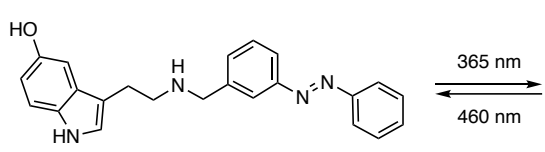

trans-Azo5HT-2

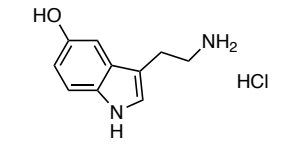

$\mathrm{NaBH}_{3} \mathrm{CN}, \mathrm{NEt}_{3}$, EtOH, 1h, rt
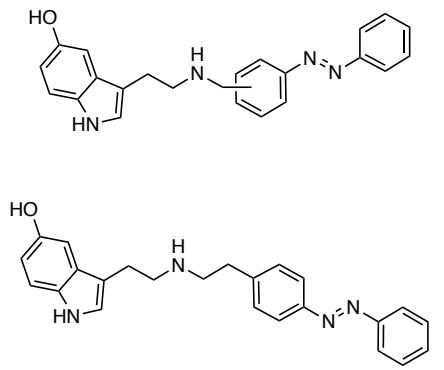

trans-Azo5HT-3

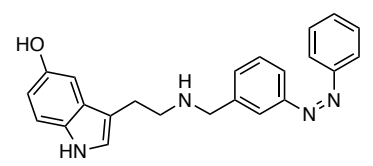

cis-Azo5HT-2
C

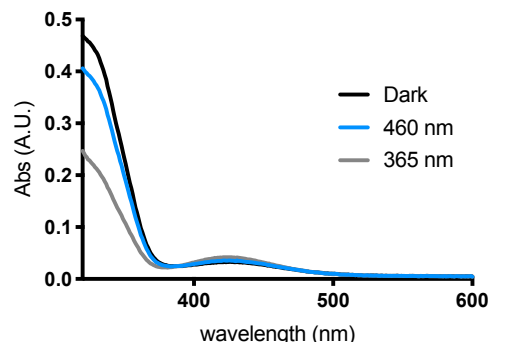

D

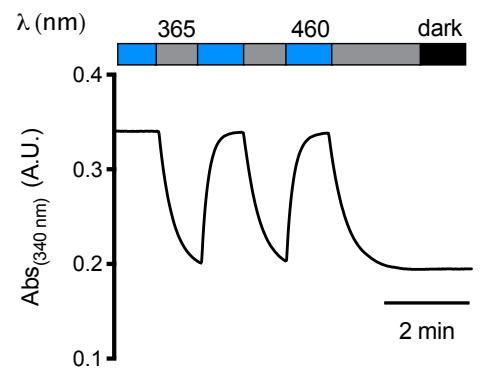

Figure 2. Synthesis and photophysical characterization of photoswitchable 5-HT derivatives Azo5HT-1-3. 
To assess the ability of Azo5HT molecules to serve as 5-HTR agonists, we tested each compound across the human $5-\mathrm{HT}_{2} \mathrm{R}$ family $\left(5-\mathrm{HT}_{2 \mathrm{~A}} \mathrm{R}, 5-\mathrm{HT}_{2 \mathrm{~B}} \mathrm{R}, 5-\mathrm{HT}_{2 \mathrm{C}} \mathrm{R}\right)$. As these receptors are all $\mathrm{G}_{\mathrm{q}}-$ coupled and produce intracellular $\mathrm{Ca}^{2+}$ release via phospholipase $\mathrm{C}-\beta$ activation, we performed live cell $\mathrm{Ca}^{2+}$ imaging with the fluorescent sensor, GCaMP6f. Using this assay, all three receptors showed the expected 5-HT responses with $\mathrm{nM} \mathrm{EC}_{50}$ values (Table 1). Compounds Azo5HT-1-3 were tested independently either under standard conditions with $488 \mathrm{~nm}$ illumination for GCaMP6f excitation, which maintain them in the trans state, or with interweaved $385 \mathrm{~nm}$ illumination to convert them to the cis state. All three compounds showed dose-dependent activation of $5-\mathrm{HT}_{2 \mathrm{~A}} \mathrm{R}$ in the trans and cis states with a leftward shift in the cis state (Fig. 3A; Fig. S2). For Azo5HT-1 there was a 2-fold shift, while a larger 5-10-fold shift was seen for Azo5HT-2 and Azo5HT-3 (Table 1). It's worth noting that $385 \mathrm{~nm}$ likely does not maximally occupy the cis state, so the relative difference between cis and trans may be underestimated using this approach. In contrast to the $5-\mathrm{HT}_{2 \mathrm{~A}} \mathrm{R}$, no or very modest differences were observed between cis and trans for each molecule on 5- $\mathrm{HT}_{2 \mathrm{~B}} \mathrm{R}$ and 5- $\mathrm{HT}_{2 \mathrm{C}} \mathrm{R}$ (Table 1; Fig. S2).

A
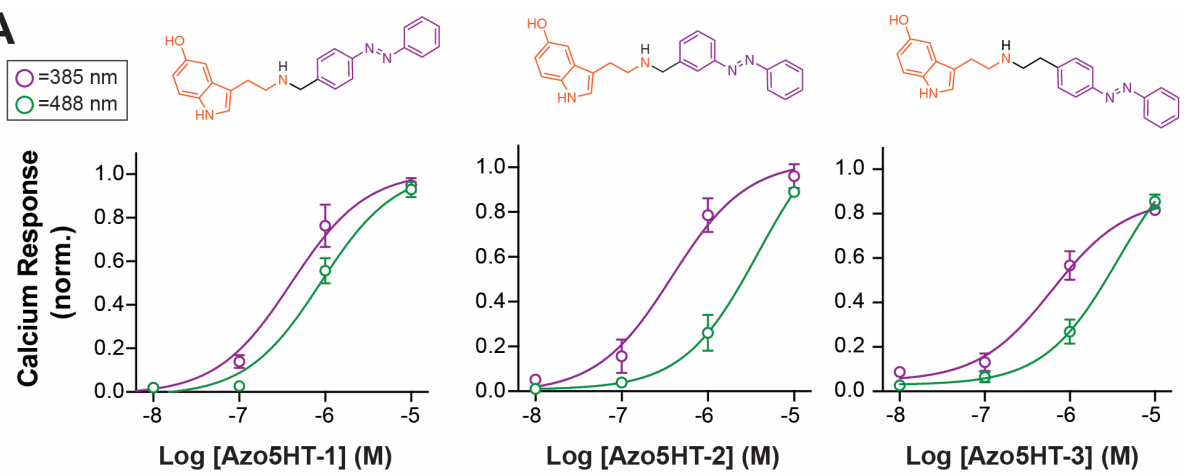

B

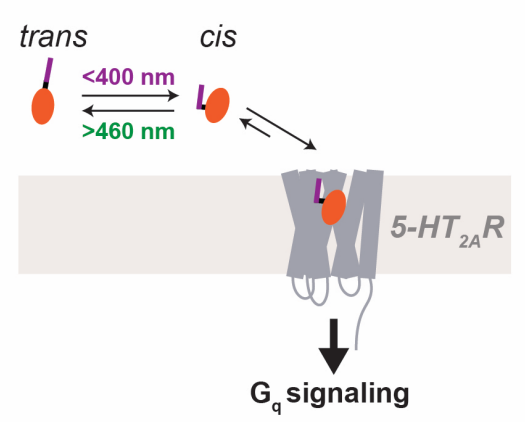

C

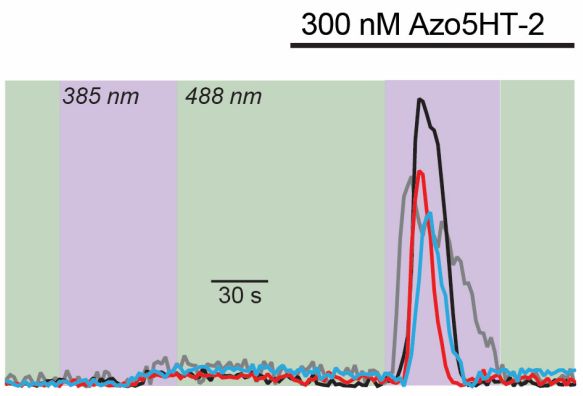

Figure 3. Photoactivation of 5-HT2AR by Azo5HT-2. (A) Dose-response curves for Azo5HT compounds showing enhanced agonism for cis versus trans for all compounds using a $\mathrm{Ca}^{2+}$ imaging assay. (see Table 
S1). (B) Schematic of Azo5HT-2 mediated optical control. (C) Representative $\mathrm{Ca}^{2+}$ imaging traces showing photoactivation of 5-HT ${ }_{2 A} \mathrm{R}$ by Azo5HT-2. In the absence of Azo5HT-2, no $385 \mathrm{~nm}$ light response is seen but a clear response is seen in the presence of $300 \mathrm{nM}$ Azo5HT-2 with similar on and desensitization kinetics compared to 5-HT application (see Fig. S4).

Next, we asked if Azo5HT-2 photoconversion could be harnessed for optical activation of 5- $\mathrm{HT}_{2 \mathrm{~A}} \mathrm{R}$ (Fig. 3B). Application of 100-300 nM Azo5HT-2 produced minimal responses under $488 \mathrm{~nm}$ illumination but following application of $385 \mathrm{~nm}$ light, clear responses were observed that were up to $50 \%$ in amplitude relative to saturating 5-HT (Fig. 3C; Fig. S4A-B). Together, these data indicate that Azo5HT-2 enables reversible photoagonism of $5-\mathrm{HT}_{2 \mathrm{~A}} \mathrm{R}$ with similar signaling properties to the endogenous agonist $5-\mathrm{HT}$.

We next used computational ligand docking to gain insight into the binding mode of Azo5HT-2 using the recently reported LSD-bound crystal structure of the 5- $\mathrm{HT}_{2 \mathrm{~A}} \mathrm{R} .{ }^{43}$ Cis-Azo5HT-2 showed similar binding of the $5-\mathrm{HT}$ moiety compared to $5-\mathrm{HT}$ alone (Fig. 4A, B) and the azobenzene moiety showed occupancy of a pocket toward the extracellular face of the receptor with likely solvent accessibility from the cell surface (Fig. 4B, Fig. S5A). In contrasts, trans-Azo5HT-2 showed variable docking results with a lower proportion of docks containing a canonical pose (see SI for details) for the 5-HT moiety (24/78 for cis-Azo5HT-2 versus 7/41 for trans-Azo5HT-2 versus 25/95 for 5-HT) (Fig. S5B, C). Based on the potential binding pose of cis-Azo5HT-2, we reasoned that extension of this molecule would be tolerated and, ultimately, enable tethering to a labeling site (e.g. SNAP-tag) outside the core of the transmembrane helix bundle and extracellular loops of the receptor. To test this, we synthesized the extended photoswitch BocAzo5HT-2 (Fig. 4C) using our established reductive amination conditions (Fig. S2). Boc-Azo5HT-2 showed clear agonism of $5-\mathrm{HT}_{2 \mathrm{~A}} \mathrm{R}$ and maintained enhanced apparent affinity in the cis state (Fig. 4C; Table 1), enabling photo-activation of $\mathrm{Ca}^{2+}$ responses (Fig. S6).

Motivated by our docking and Boc-Azo5HT-2 test compound analysis, we designed PORTLs with the goal of enabling tethered optical control of SNAP-5HT ${ }_{2 A} R$ (Fig. 4D). To this end, BOC-Azo5HT-2 was deprotected and various PEG-linkers and benzyl guanine (BG) were attached through successive amide couplings (Fig. S3). We first used a previously established fluorophore competition labeling assay ${ }^{30}$ to 
confirm that all PORTLs efficiently label N-terminally SNAP-tagged 5- $\mathrm{HT}_{2 A} R$ ("SNAP-5HT $2 A$ ") (Fig. S7A,

B). We then tested the ability of each PORTL to produce optically-evoked $\mathrm{Ca}^{2+}$ responses following conjugation to SNAP-5HT $2 \mathrm{~A}$ R and $385 \mathrm{~nm}$ illumination. Reversible and repeatable $385 \mathrm{~nm}$ light-evoked $\mathrm{Ca}^{2+}$ transients were seen with all 3 PORTL variants in $10-40 \%$ of cells with a higher proportion of cells showing photoactivation with BG-Azo5HT 24 and BG-Azo5HT 12 compared to BG-Azo5HT (Fig. S7C, D). Light responses were not seen in the absence of PORTL labeling (Fig. S7E) labeling and were as large as $60 \%$ in amplitude relative to saturating 5-HT for BG-Azo5HT 24 and smaller for shorter variants (Fig 4F). Importantly, $385 \mathrm{~nm}$ light responses were blocked by the $5-\mathrm{HT}_{2} \mathrm{R}$ antagonist ketanserin (Fig. S7F). A subset $(<10 \%)$ of cells showed $\mathrm{Ca}^{2+}$ transients in the absence of $385 \mathrm{~nm}$ illumination (Fig. S7G), likely indicative of some activation via the PORTL in trans. This potential trans activation was more pronounced in shorter variants, suggesting that the decreased local concentration associated with longer PORTLs enhances the relative cis versus trans agonism via the Azo5HT moiety. Together, these data establish genetically targetable, PORTL-mediated optical control of $5-\mathrm{HT}_{2 \mathrm{~A}} \mathrm{R}$ and provide a strong foundation for both further engineering and application.

A

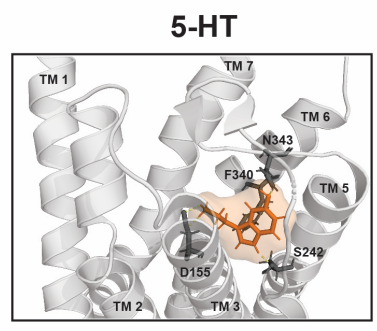

B

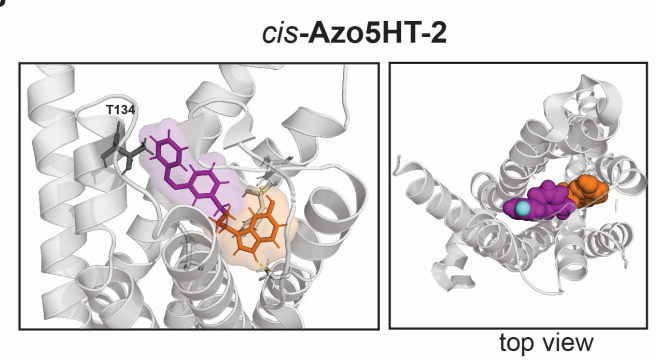

C

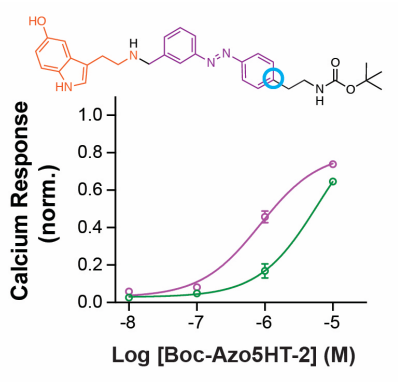

D<smiles>[2H]C</smiles>
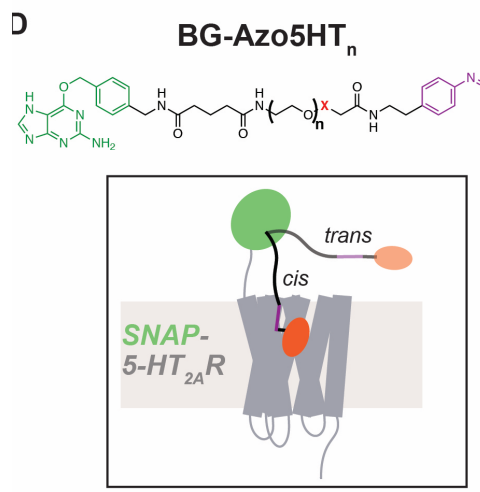

E SNAP-5HT $2 \mathrm{~A}$ R + BG-Azo5HT 24 F

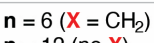

$\mathrm{n}=12($ no $X)$

$\mathbf{n}=24\left(\mathrm{X}=\mathrm{CH}_{2}\right)$

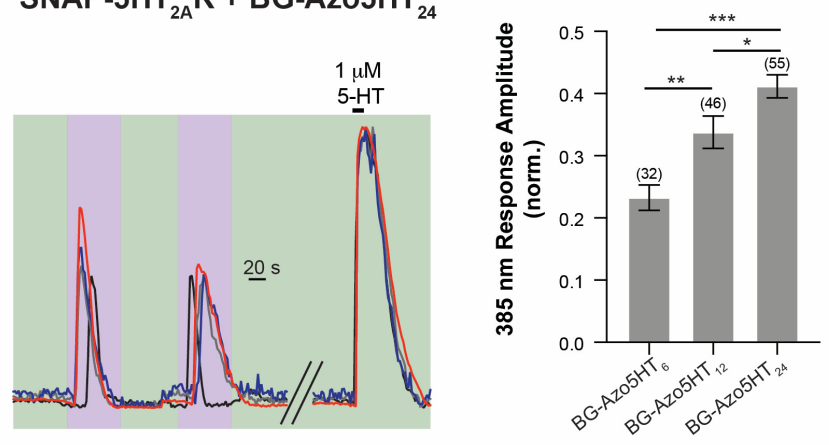


144 Figure 4. Docking and test compound analysis enable PORTL development. (A-B) Docking analysis 145 showing that both 5-HT (A) and the 5-HT moiety of Azo5HT-2 (B) show identical poses, with the azobenzene moiety occupying a water-filled cavity at the extracellular face of $5-\mathrm{HT}_{2 \mathrm{~A}} \mathrm{R}$. Residues associated with canonical 5-HT binding are highlighted in (A) and position T134, which was previously

148 substituted for conjugation of a covalent $5-\mathrm{HT}_{2 A} \mathrm{R}$ agonist ${ }^{42}$, is highlighted in $(\mathrm{B})$. Top view (B, right) shows 149 that the para position (yellow) is positioned facing toward the extracellular solution. C) Chemical structure 150 (top; para position circled in yellow) and dose response curve (bottom) showing light-dependent 151 (purple=385 nm illumination; green=488 nm illumination) activation of 5-HT ${ }_{2 A} R$ by Boc-Azo5HT-2. (D)

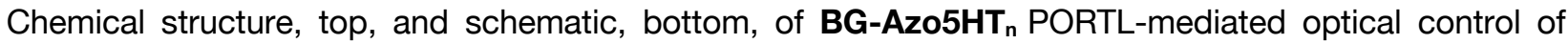
153 SNAP-tagged 5-HT $2 \mathrm{~A}$. (E-F) Representative traces (F) and summary bar graph (G) showing photoactivation of SNAP-5-HT $2 \mathrm{~A}$ R by BG-Azo5HT $\mathrm{H}_{\mathbf{n}}$ PORTLs. The numbers of cells analyzed are shown in parentheses. * indicates statistical significance (1-way ANOVA with Tukey-Kramer Multiple Comparisons; $\mathrm{p}=0.0068$ for $\mathrm{BG}-\mathrm{Azo5HT_{6 }}$ vs. BG-Azo5HT $12, \mathrm{p}<0.0001$ for $\mathrm{BG}-\mathrm{Azo} 5 \mathrm{HT}_{6}$ vs. $\mathrm{BG}-\mathrm{Azo} 5 \mathrm{HT}_{24}, \mathrm{p}=0.036$ for $\mathrm{BG}-$ Azo5HT 12 vs. BG-Azo5HT 24$)$

In summary, we have developed first-in-class photoswitchable analogs of serotonin that allow for the optical control of 5-HT ${ }_{2 A} R$. Interestingly, all three test compounds, Azo5HT1-3 showed preferential agonism in cis over trans on the $5-\mathrm{HT}_{2 \mathrm{~A}} \mathrm{R}$, but no clear difference between states on the $5-\mathrm{HT}_{2 \mathrm{~B}} \mathrm{R}$ or 5 $\mathrm{HT}_{2 \mathrm{C}} \mathrm{R}$, providing a powerful chemical lead for further molecular pharmacological analysis. At the appropriate concentrations (100-300 nM), our lead compound Azo5HT-2 is inactive in the dark and becomes an effective agonist for $5-\mathrm{HT}_{2 \mathrm{~A}} \mathrm{R}$ following illumination. While Azo5HT-2 offers the advantage of being based on the endogenous $5-\mathrm{HT}$ ligand, the design employed likely provides a template for azologization of other 5-HTR agonists, including psilocin and LSD which all contain a shared tryptamine motif. Furthermore, this study establishes the proof-of-principle of photopharmacology for 5 -HTRs and should provide a basis for extension of this approach to other 5-HTR subfamilies, including those that are $\mathrm{Gi}_{/ \circ}\left(5-\mathrm{HT}_{1} \mathrm{Rs}, 5-\mathrm{HT}_{5} \mathrm{Rs}\right)$ or $\mathrm{G}_{\mathrm{s}}\left(5-\mathrm{HT}_{4} \mathrm{R}, 5-\mathrm{HT}_{6} \mathrm{R}, 5-\mathrm{HT}_{7} \mathrm{R}\right)$-coupled. their proximity photopharmacology. BG-Azo5HT PORTLs enable reversible, repeatable optical control of 
171 SNAP- $5 \mathrm{HT}_{2 \mathrm{~A}} \mathrm{R}$, opening the door to spatiotemporally precise and genetically-targeted control of this 172 biologically important receptor. As an intriguing possibility, the PORTL technique enables incorporation of 173 mutations to the SNAP-tagged receptor that alter transducer coupling (e.g. G protein versus arrestin) or 174 regulation (e.g. phosphorylation or scaffold sites) to test their roles in a biological context. This approach 175 has long-term potential for untangling the pleiotropic antidepressant, anxiolytic, anti-addictive and 176 hallucinogenic effects of $5-\mathrm{HT}_{2 \mathrm{~A}} \mathrm{R}$ agonism. Finally, the establishment of a core PORTL for the 5- $\mathrm{HT}_{2 \mathrm{~A}} \mathrm{R}$ may 177 enable the application of next-generation PORTL approaches including branched PORTLs for dual imaging 178 and manipulation, ${ }^{33}$ spectrally fine-tuned PORTLs ${ }^{34}$ or PORTL-based strategies for targeting native 179 receptors. ${ }^{44,45}$

180

181 Associated Content

182 The Supporting Information is available free of charge at [weblink].

183 Experimental details, NMR spectra, photophysical characterization, and supporting data on cellular 184 imaging and computational ligand docking studies.

\section{Author Information}

186 "contributed equally to this study

\section{Corresponding Author}

188 *jt12003@med.cornell.edu

189 *dirktrauner@nyu.edu

190 ORCID

191 Dirk Trauner: 0000-0002-6782-6056

192 Johannes Morstein: 0000-0002-6940-288X 
Giovanna Romano: 0000-0001-7843-9425

Ambrose Plante: 0000-0003-0615-3692

\section{Acknowledgment}

We thank New York University for financial support. We thank Jordana Thibado for preliminary functional studies and SNAP- $5 \mathrm{HT}_{2 \mathrm{~A}} \mathrm{R}$ cloning. NMR spectra were acquired using the TCl cryoprobe supported by the NIH (OD016343). J.M. thanks the New York University for a Margaret and Herman Sokol fellowship, and the $\mathrm{NCl}$ for a K00 award (4K00CA253758). G.R. is supported by the Weill Cornell Molecular Biophysics Training Grant (T32GM132081). A.P. gratefully acknowledges support from NSF grant BIGDATA: IA: Collaborative Research: In Situ Data Analytics for Next Generation Molecular Dynamics Workflows (NSF \#1740990) and computational resources from (project BIP109) of the Oak Ridge Leadership Computing Facility under Contract DE-AC05-00OR22725. J.L. and D.T. are supported by an R61 (R61 DA051529) grant from NIDA. J.L. is supported by an R35 grant (R35 GM124731) from NIGMS, the Rohr Family Research Scholar Award and the Irma T. Hirschl/Monique Weill-Caulier Research Award. DT thanks the McKnight Endowment Fund for Neuroscience for a McKnight Memory and Cognitive Disorders Award.

\section{References}

(1) Nichols, D. E.; Nichols, C. D. Serotonin Receptors. Chem. Rev. 2008, 108 (5), 1614-1641. https://doi.org/10.1021/cr078224o.

(2) Berger, M.; Gray, J. A.; Roth, B. L. The Expanded Biology of Serotonin. Annu. Rev. Med. 2009, 60 (1), 355-366. https://doi.org/10.1146/annurev.med.60.042307.110802.

(3) Halberstadt, A. L.; Geyer, M. A. Multiple Receptors Contribute to the Behavioral Effects of Indoleamine Hallucinogens. Neuropharmacology 2011, $61 \quad$ (3), 364-381. https://doi.org/10.1016/j.neuropharm.2011.01.017.

(4) Cameron, L. P.; Tombari, R. J.; Lu, J.; Pell, A. J.; Hurley, Z. Q.; Ehinger, Y.; Vargas, M. V.; McCarroll, M. N.; Taylor, J. C.; Myers-Turnbull, D.; Liu, T.; Yaghoobi, B.; Laskowski, L. J.; Anderson, E. I.; Zhang, G.; Viswanathan, J.; Brown, B. M.; Tjia, M.; Dunlap, L. E.; Rabow, Z. T.; Fiehn, O.; Wulff, H.; McCorvy, J. D.; Lein, P. J.; Kokel, D.; Ron, D.; Peters, J.; Zuo, Y.; Olson, D. E. A Non-Hallucinogenic Psychedelic Analogue with Therapeutic Potential. Nature 2021, 589 (7842), 474-479. https://doi.org/10.1038/s41586-020-3008-z.

(5) Nutt, D.; Erritzoe, D.; Carhart-Harris, R. Psychedelic Psychiatry's Brave New World. Cell 2020, 181 (1), 24-28. https://doi.org/10.1016/j.cell.2020.03.020.

(6) Dong, C.; Ly, C.; Dunlap, L. E.; Vargas, M. V.; Sun, J.; Hwang, I.-W.; Azinfar, A.; Oh, W. C.; Wetsel, W. C.; Olson, D. E.; Tian, L. Psychedelic-Inspired Drug Discovery Using an Engineered Biosensor. Cell 2021, 184 (10), 2779-2792.e18. https://doi.org/10.1016/j.cell.2021.03.043. 
(7) Shao, L.-X.; Liao, C.; Gregg, I.; Davoudian, P. A.; Savalia, N. K.; Delagarza, K.; Kwan, A. C. Psilocybin Induces Rapid and Persistent Growth of Dendritic Spines in Frontal Cortex in Vivo. Neuron 2021, S0896-6273(21)00423-2. https://doi.org/10.1016/j.neuron.2021.06.008.

(8) Beharry, A. A.; Woolley, G. A. Azobenzene Photoswitches for Biomolecules. Chem. Soc. Rev. 2011, 40 (8), 4422-4437. https://doi.org/10.1039/C1CS15023E.

(9) Szymański, W.; Beierle, J. M.; Kistemaker, H. A. V.; Velema, W. A.; Feringa, B. L. Reversible Photocontrol of Biological Systems by the Incorporation of Molecular Photoswitches. Chem. Rev. 2013, 113 (8), 6114-6178. https://doi.org/10.1021/cr300179f.

(10) Hüll, K.; Morstein, J.; Trauner, D. In Vivo Photopharmacology. Chem. Rev. 2018, 118 (21), 1071010747. https://doi.org/10.1021/acs.chemrev.8b00037.

(11) Schönberger, M.; Trauner, D. A Photochromic Agonist for $\mu$-Opioid Receptors. Angew. Chem. Int. Ed. 2014, 53 (12), 3264-3267. https://doi.org/10.1002/anie.201309633.

(12) Lachmann, D.; Studte, C.; Männel, B.; Hübner, H.; Gmeiner, P.; König, B. Photochromic Dopamine Receptor Ligands Based on Dithienylethenes and Fulgides. Chem. - Eur. J. 2017, 23 (54), 1342313434. https://doi.org/10.1002/chem.201702147.

(13) Donthamsetti, P. C.; Winter, N.; Schönberger, M.; Levitz, J.; Stanley, C.; Javitch, J. A.; Isacoff, E. Y.; Trauner, D. Optical Control of Dopamine Receptors Using a Photoswitchable Tethered Inverse Agonist. J. Am. Chem. Soc. 2017, 139 (51), 18522-18535. https://doi.org/10.1021/jacs.7b07659.

(14) Hauwert, N. J.; Mocking, T. A. M.; Da Costa Pereira, D.; Lion, K.; Huppelschoten, Y.; Vischer, H. F.; De Esch, I. J. P.; Wijtmans, M.; Leurs, R. A Photoswitchable Agonist for the Histamine H3 Receptor, a Prototypic Family A G-Protein-Coupled Receptor. Angew. Chem. Int. Ed. 2019, 58 (14), 4531-4535. https://doi.org/10.1002/anie.201813110.

(15) Bahamonde, M. I.; Taura, J.; Paoletta, S.; Gakh, A. A.; Chakraborty, S.; Hernando, J.; FernándezDueñas, V.; Jacobson, K. A.; Gorostiza, P.; Ciruela, F. Photomodulation of G Protein-Coupled Adenosine Receptors by a Novel Light-Switchable Ligand. Bioconjug. Chem. 2014, 25 (10), 18471854. https://doi.org/10.1021/bc5003373.

(16) Agnetta, L.; Kauk, M.; Canizal, M. C. A.; Messerer, R.; Holzgrabe, U.; Hoffmann, C.; Decker, M. A Photoswitchable Dualsteric Ligand Controlling Receptor Efficacy. Angew. Chem. Int. Ed. 2017, 56 (25), 7282-7287. https://doi.org/10.1002/anie.201701524.

(17) Prischich, D.; Gomila, A. M. J.; Milla-Navarro, S.; Sangüesa, G.; Diez-Alarcia, R.; Preda, B.; Matera, C.; Batlle, M.; Ramírez, L.; Giralt, E.; Hernando, J.; Guasch, E.; Meana, J. J.; Villa, P. de la; Gorostiza, P. Adrenergic Modulation With Photochromic Ligands. Angew. Chem. Int. Ed. 2021, 60 (7), 36253631. https://doi.org/10.1002/anie.202010553.

(18) Frank, J. A.; Yushchenko, D. A.; Fine, N. H. F.; Duca, M.; Citir, M.; Broichhagen, J.; Hodson, D. J.; Schultz, C.; Trauner, D. Optical Control of GPR40 Signalling in Pancreatic $\beta$-Cells. Chem. Sci. 2017, 8 (11), 7604-7610. https://doi.org/10.1039/C7SC01475A.

(19) Morstein, J.; Hill, R. Z.; Novak, A. J. E.; Feng, S.; Norman, D. D.; Donthamsetti, P. C.; Frank, J. A.; Harayama, T.; Williams, B. M.; Parrill, A. L.; Tigyi, G. J.; Riezman, H.; Isacoff, E. Y.; Bautista, D. M.; Trauner, D. Optical Control of Sphingosine-1-Phosphate Formation and Function. Nat. Chem. Biol. 2019, 15 (6), 623. https://doi.org/10.1038/s41589-019-0269-7.

(20) Morstein, J.; Dacheux, M. A.; Norman, D. D.; Shemet, A.; Donthamsetti, P. C.; Citir, M.; Frank, J. A.; Schultz, C.; Isacoff, E. Y.; Parrill, A. L.; Tigyi, G. J.; Trauner, D. Optical Control of Lysophosphatidic Acid Signaling. J. Am. Chem. Soc. 2020, 142 (24), 10612-10616. https://doi.org/10.1021/jacs.0c02154.

(21) Westphal, M. V.; Schafroth, M. A.; Sarott, R. C.; Imhof, M. A.; Bold, C. P.; Leippe, P.; Dhopeshwarkar, A.; Grandner, J. M.; Katritch, V.; Mackie, K.; Trauner, D.; Carreira, E. M.; Frank, J. A. Synthesis of Photoswitchable $\Delta 9$-Tetrahydrocannabinol Derivatives Enables Optical Control of Cannabinoid Receptor 1 Signaling. J. Am. Chem. Soc. 2017, 139 (50), 18206-18212. https://doi.org/10.1021/jacs.7b06456.

(22) Sarott, R. C.; Viray, A. E. G.; Pfaff, P.; Sadybekov, A.; Rajic, G.; Katritch, V.; Carreira, E. M.; Frank, J. A. Optical Control of Cannabinoid Receptor 2-Mediated Ca2+ Release Enabled by Synthesis of Photoswitchable Probes. J. Am. Chem. Soc. 2021, 143 (2), 736-743. https://doi.org/10.1021/jacs.0c08926. 
(23) Broichhagen, J.; Johnston, N. R.; von Ohlen, Y.; Meyer-Berg, H.; Jones, B. J.; Bloom, S. R.; Rutter, G. A.; Trauner, D.; Hodson, D. J. Allosteric Optical Control of a Class B G-Protein-Coupled Receptor. Angew. Chem. Int. Ed Engl. 2016, 55 (19), 5865-5868. https://doi.org/10.1002/anie.201600957.

(24) Broichhagen, J.; Podewin, T.; Meyer-Berg, H.; von Ohlen, Y.; Johnston, N. R.; Jones, B. J.; Bloom, S. R.; Rutter, G. A.; Hoffmann-Röder, A.; Hodson, D. J.; Trauner, D. Optical Control of Insulin Secretion Using an Incretin Switch. Angew. Chem. Int. Ed. 2015, 54 (51), 15565-15569. https://doi.org/10.1002/anie.201506384.

(25) Pittolo, S.; Gómez-Santacana, X.; Eckelt, K.; Rovira, X.; Dalton, J.; Goudet, C.; Pin, J.-P.; Llobet, A.; Giraldo, J.; Llebaria, A.; Gorostiza, P. An Allosteric Modulator to Control Endogenous G ProteinCoupled Receptors with Light. Nat. Chem. Biol. 2014, 10 (10), 813-815. https://doi.org/10.1038/nchembio.1612.

(26) Rovira, X.; Trapero, A.; Pittolo, S.; Zussy, C.; Faucherre, A.; Jopling, C.; Giraldo, J.; Pin, J.-P.; Gorostiza, P.; Goudet, C.; Llebaria, A. OptoGluNAM4.1, a Photoswitchable Allosteric Antagonist for Real-Time Control of MGlu4 Receptor Activity. Cell Chem. Biol. 2016, 23 (8), 929-934. https://doi.org/10.1016/j.chembiol.2016.06.013.

(27) Font, J.; López-Cano, M.; Notartomaso, S.; Scarselli, P.; Di Pietro, P.; Bresolí-Obach, R.; Battaglia, G.; Malhaire, F.; Rovira, X.; Catena, J.; Giraldo, J.; Pin, J.-P.; Fernández-Dueñas, V.; Goudet, C.; Nonell, S.; Nicoletti, F.; Llebaria, A.; Ciruela, F. Optical Control of Pain in Vivo with a Photoactive MGlu5 Receptor Negative Allosteric Modulator. elife 2017, 6, e23545. https://doi.org/10.7554/eLife.23545.

(28) Donthamsetti, P.; Konrad, D. B.; Hetzler, B.; Fu, Z.; Trauner, D.; Isacoff, E. Y. Selective Photoswitchable Allosteric Agonist of a G Protein-Coupled Receptor. J. Am. Chem. Soc. 2021, 143 (24), 8951-8956. https://doi.org/10.1021/jacs.1c02586.

(29) Broichhagen, J.; Damijonaitis, A.; Levitz, J.; Sokol, K. R.; Leippe, P.; Konrad, D.; Isacoff, E. Y.; Trauner, D. Orthogonal Optical Control of a G Protein-Coupled Receptor with a SNAP-Tethered Photochromic Ligand. ACS Cent. Sci. 2015, 1 (7), 383-393. https://doi.org/10.1021/acscentsci.5b00260.

(30) Levitz, J.; Broichhagen, J.; Leippe, P.; Konrad, D.; Trauner, D.; Isacoff, E. Y. Dual Optical Control and Mechanistic Insights into Photoswitchable Group II and III Metabotropic Glutamate Receptors. Proc. Natl. Acad. Sci. 2017, 114 (17), E3546-E3554. https://doi.org/10.1073/pnas.1619652114.

(31) Levitz, J.; Habrian, C.; Bharill, S.; Fu, Z.; Vafabakhsh, R.; Isacoff, E. Y. Mechanism of Assembly and Cooperativity of Homomeric and Heteromeric Metabotropic Glutamate Receptors. Neuron 2016, 92 (1), 143-159. https://doi.org/10.1016/j.neuron.2016.08.036.

(32) Berry, M. H.; Holt, A.; Salari, A.; Veit, J.; Visel, M.; Levitz, J.; Aghi, K.; Gaub, B. M.; Sivyer, B.; Flannery, J. G.; Isacoff, E. Y. Restoration of High-Sensitivity and Adapting Vision with a Cone Opsin. Nat. Commun. 2019, 10 (1), 1221. https://doi.org/10.1038/s41467-019-09124-X.

(33) Acosta-Ruiz, A.; Gutzeit, V. A.; Skelly, M. J.; Meadows, S.; Lee, J.; Parekh, P.; Orr, A. G.; Liston, C.; Pleil, K. E.; Broichhagen, J.; Levitz, J. Branched Photoswitchable Tethered Ligands Enable UltraEfficient Optical Control and Detection of G Protein-Coupled Receptors In Vivo. Neuron 2020, 105 (3), 446-463.e13. https://doi.org/10.1016/j.neuron.2019.10.036.

(34) Gutzeit, V. A.; Acosta-Ruiz, A.; Munguba, H.; Häfner, S.; Landra-Willm, A.; Mathes, B.; Mony, J.; Yarotski, D.; Börjesson, K.; Liston, C.; Sandoz, G.; Levitz, J.; Broichhagen, J. A Fine-Tuned Azobenzene for Enhanced Photopharmacology in Vivo. Cell Chem. Biol. 2021. https://doi.org/10.1016/j.chembiol.2021.02.020.

(35) Cabrera, R.; Filevich, O.; García-Acosta, B.; Athilingam, J.; Bender, K. J.; Poskanzer, K. E.; Etchenique, R. A Visible-Light-Sensitive Caged Serotonin. ACS Chem. Neurosci. 2017, 8 (5), 10361042. https://doi.org/10.1021/acschemneuro.7b00083.

(36) Rea, A. C.; Vandenberg, L. N.; Ball, R. E.; Snouffer, A. A.; Hudson, A. G.; Zhu, Y.; McLain, D. E.; Johnston, L. L.; Lauderdale, J. D.; Levin, M.; Dore, T. M. Light-Activated Serotonin for Exploring Its Action in Biological Systems. Chem. Biol. 2013, 20 (12), 1536-1546. https://doi.org/10.1016/j.chembiol.2013.11.005.

(37) Zayat, L.; Salierno, M.; Etchenique, R. Ruthenium(II) Bipyridyl Complexes as Photolabile Caging Groups for Amines. Inorg. Chem. 2006, 45 (4), 1728-1731. https://doi.org/10.1021/ic0512983.

(38) Breitinger, H.-G. A.; Wieboldt, R.; Ramesh, D.; Carpenter, B. K.; Hess, G. P. Synthesis and Characterization of Photolabile Derivatives of Serotonin for Chemical Kinetic Investigations of the 
(39) Donthamsetti, P. C.; Broichhagen, J.; Vyklicky, V.; Stanley, C.; Fu, Z.; Visel, M.; Levitz, J. L.; Javitch, J. A.; Trauner, D.; Isacoff, E. Y. Genetically Targeted Optical Control of an Endogenous G ProteinCoupled Receptor. J. Am. Chem. Soc. 2019, 141 (29), 11522-11530. https://doi.org/10.1021/jacs.9b02895.

(40) Broichhagen, J.; Frank, J. A.; Trauner, D. A Roadmap to Success in Photopharmacology. Acc. Chem. Res. 2015, 48 (7), 1947-1960. https://doi.org/10.1021/acs.accounts.5b00129.

(41) Morstein, J.; Awale, M.; Reymond, J.-L.; Trauner, D. Mapping the Azolog Space Enables the Optical Control of New Biological Targets. ACS Cent. Sci. 2019, 5 (4), 607-618. https://doi.org/10.1021/acscentsci.8b00881.

(42) Weichert, D.; Kruse, A. C.; Manglik, A.; Hiller, C.; Zhang, C.; Hübner, H.; Kobilka, B. K.; Gmeiner, P. Covalent Agonists for Studying G Protein-Coupled Receptor Activation. Proc. Natl. Acad. Sci. 2014, 111 (29), 10744-10748. https://doi.org/10.1073/pnas.1410415111.

(43) Kim, K.; Che, T.; Panova, O.; DiBerto, J. F.; Lyu, J.; Krumm, B. E.; Wacker, D.; Robertson, M. J.; Seven, A. B.; Nichols, D. E.; Shoichet, B. K.; Skiniotis, G.; Roth, B. L. Structure of a HallucinogenActivated Gq-Coupled 5-HT2A Serotonin Receptor. Cell 2020, 182 (6), 1574-1588.e19. https://doi.org/10.1016/j.cell.2020.08.024.

(44) Farrants, H.; Gutzeit, V. A.; Acosta-Ruiz, A.; Trauner, D.; Johnsson, K.; Levitz, J.; Broichhagen, J. SNAP-Tagged Nanobodies Enable Reversible Optical Control of a G Protein-Coupled Receptor via a Remotely Tethered Photoswitchable Ligand. ACS Chem. Biol. 2018, 13 (9), 2682-2688. https://doi.org/10.1021/acschembio.8b00628.

(45) Donthamsetti, P. C.; Broichhagen, J.; Vyklicky, V.; Stanley, C.; Fu, Z.; Visel, M.; Levitz, J. L.; Javitch, J. A.; Trauner, D.; Isacoff, E. Y. Genetically Targeted Optical Control of an Endogenous G ProteinCoupled Receptor. J. Am. Chem. Soc. 2019, 141 (29), 11522-11530. https://doi.org/10.1021/jacs.9b02895. 

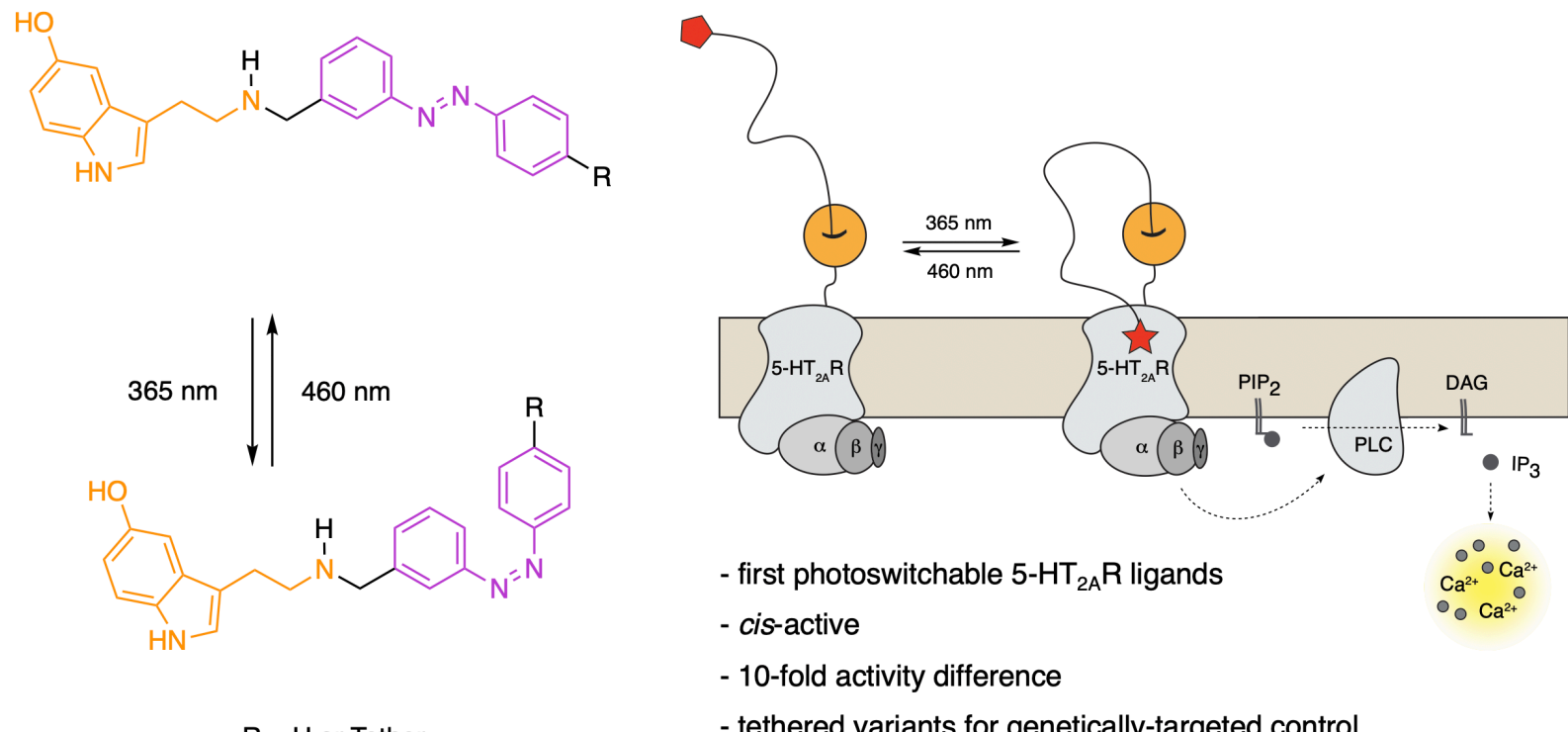

365 